\title{
空中写真を利用した裸地地域の土砂生産調査の方法について*
}

\author{
中山! 政一 **.今村 遼平 $* *$
}

\section{On Photogrammetric Investigation Method of the Debris Produced in Bare Mountainside}

\author{
by Masaichi Nakayama and Ryohei Imamura
}

\begin{abstract}
The definite investigation method of the debris volume derived from the bare mountainside has not been established. Around the Ashio desolate mountainous area, photogrammetric comparative measurement of surface height of some model zones settled on mountainside is carried out through the large airphotographs taken at intervals of about one year by helicopter. Mean deviation value of height of each model zones is applied to all mountainside classified to each type beforehand by photointerpretation to tctalize the produced volume of debris. Though the measurement error is estimated as about $\pm 3.6 \mathrm{~cm}$, this method is considered to be effective for this purpose at nowaday.
\end{abstract}

はじめに 崩壊地のらち, いわゆる豪雨型崩壊からの 生産土砂量算出は, 従来から空中写真判読と現地での サンプル崩壊地調查を併用した方法により，各地で行 なわれて掠り，方法的こもほぼ確立されているといえ よう。

一方，広域こわたる裸地地域あるいは大規模崩壊地 での生産土砂量の算出方法として，これまでにも(1)モ デル区域に和ける杭による測定方法, (2)モデル地から の流出土砂を，直接特製の土砂だめにうけて測定する 方法などが試みられているが，経費と精度の点で問題 があった。

以前筆者らは, 高瀬川支流の濁沢 - 不動沢流域に掠 いて, かかる裸地地域での侵食量を求めるために，空 中写真を使用した(東京電力：1967)。しかし，その際 には，モデル区域内に基準点の数が少なく，また使用 写真が $1 / 2,400$ (初回 $1 / 1,250,2$ 回目 $1 / 2,400$ )の固定 翼機によるものであったため，精度上必ずしも期待ど うりの成果が得られたとは言えず，結局，裸地地域の 生産土砂量の算出方法は，未確立のままであった。

その後，筆者らは1967年から 4 年間にわたり，広大 な荒廃裸地を有する足尾三川地区 (図一1) において, この種の調査を実施する機会を得た。調査は，写真撮

* 昭和 47 年度 写真測量学会総会にて発表

**国際航業(株) 地質一部

「写真測量」Vol.12 No. 31973

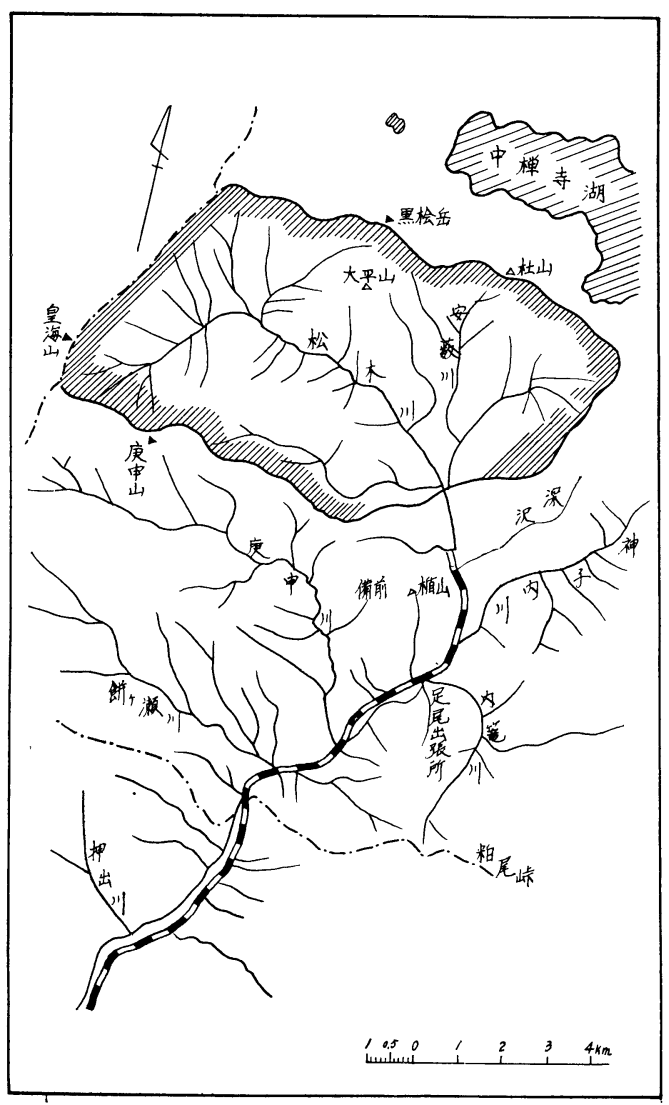

図一 1 足尾三川地区位置図 
影冗はじまり，傾斜分類図，地表地質図，砂防・治山 立地区分図，土砂生産機構区分図の作成なぞ，山腹性 状の定性的把握の段階をへて，最終的には選定した20 個所のモデル区域で算出した 2 時期間の平均侵食深を もとに，対象地域全域の生産土砂量を算出するという 定量的調査をもって終えた。この空中写真を使った表 面侵食量調查の方法が，最良の方法であるとはいえな いが，ここに報告し，大方の御批判をあおぐものであ る。

小論をまとめるにあたり，種々の便宜をはかってい ただいた建設省渡良瀬川工事事務所や林野庁前橋営林 局および国際航業(㑣測量・地質両部の関係各位抢よび 原稿の監修を扔願いした垣下精三氏には，深起なる感 謝の意を表するものである。

\section{1. 地質図の作成}

対象地域は，いわゆる秩父古生層の粘板岩を基盤と し，これを貫く石英閃緑岩やいわゆる奥日光流紋岩な ぞの分布する荒廃山地である。全域的 $56 \mathrm{~km}^{2}$ について 写真判読と現地踏査により，1/5,000 地質図を作成し た。判読には，裸地地域約 $30 \mathrm{~km}^{2}$ については，主とし て $1 / 5,000$ カラー写真を，また植生被覆地域について は1/10,000パンクロ写真を使用した。地質図作成に際 しては，とくに未固結堆積物，裂か系の判読に重点を 抢き，土砂生産の素因としての地質状況の把握につと めた。

\section{2. 砂防・治山立地区分}

荒廃した足尾山地の砂防・治山構造物のうち，足尾 えん堤をはじめとする数多くのえん堤が，流出土砂の かん止に有効作用していることは，河床変動量調查 によっても明かであるが(中山ら：1967)，さらに，今 後河川への土砂流出を防止する山腹基礎工，緑化工の 重要性も見のがせない。ただ当地域の場合，地形・地 質・気象・侵食力の大きさ等，砂防・治山作業以前の 悪条件が重なって㧍り，これを克服して山地の荒廃復 旧・予防を行うためには，まず山腹の現況を詳細に知 る必要がある。

このため，全域について「砂防・治山立地区分図」 を作成した。これは流域後背山地の山腹と河床の状沉 を自然のまま，上位から優先的に図示するのを原則と した。すなわち上位より，1）植生被覆区分，2）未 固結堆積物区分，3）岩石の風化状態区分，4）地質 区分，などをな行ない,その伍か，5）山腹斜面の侵食 地形区分として，崩壊地と侵食路を図示した(表一1)。

判読こは，とく荒廃の著しい足尾三川 地区約 30 $\mathrm{km}^{2}$ については $1 / 5,000$ カラー写真を使用し，結果は

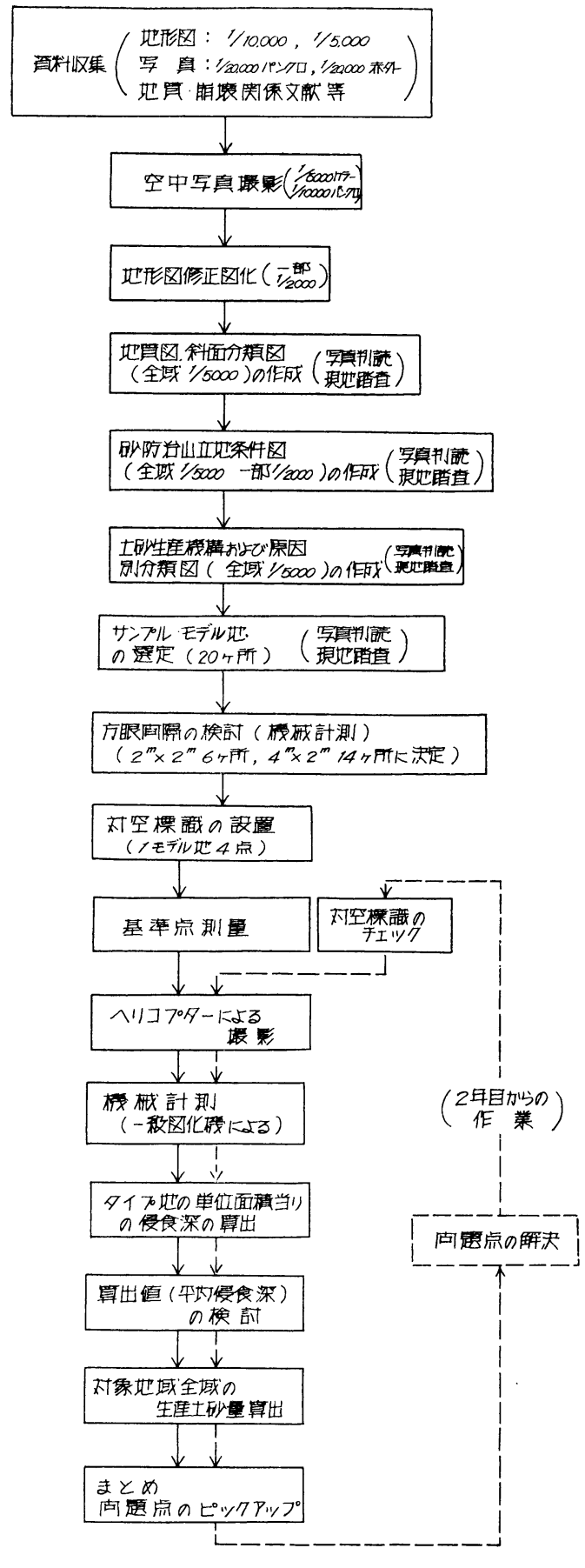

図一2 調查作業の流れ

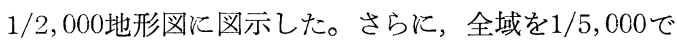
図示したが，その際植生の多い非荒廃地域では，1/ 25,000パンクロ写真を使用した。

\section{3. 土砂生産機構区分}

全域を，土砂生産機構もしくは崩壊原因に重点を扝 
表-1 砂防治山立地区分一覧表

\begin{tabular}{|c|c|c|}
\hline 大区分 & 細 区 分 & \\
\hline \multirow{2}{*}{$\begin{array}{l}\text { 植区 } \\
\text { 䈨 } \\
\text { 覆 }\end{array}$} & 森林 & 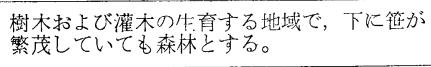 \\
\hline & 草 生 地 & 笹その他いわ的る雑草の繁茂するところ \\
\hline \multirow{7}{*}{ 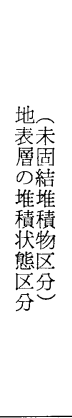 } & 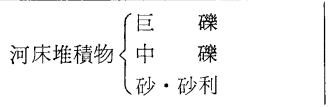 & 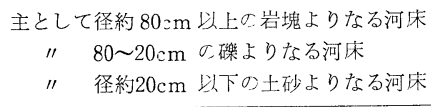 \\
\hline & 崖錐堆積物または扇状地堆積物 & 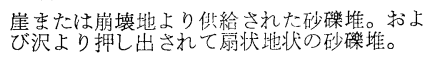 \\
\hline & \multirow{3}{*}{ 段丘堆積物 } & \multirow{3}{*}{$\begin{array}{l}\text { 河床の変動により河床に形成された砂碑堆で } \\
\text { 平坦面をなすもの。高位 (HTr),中位 ( } \mathrm{Tr} \text { ) } \\
\text { 低位 (LTr)に3区分した。 }\end{array}$} \\
\hline & & \\
\hline & & \\
\hline & 鉱㵏 & 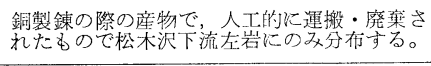 \\
\hline & ロームまたは礫まじりローム & \\
\hline \multirow{3}{*}{$\begin{array}{l}\text { 岩態 } \\
\text { 的 } \\
\text { 風 } \\
\text { 华 } \\
\text { 状 }\end{array}$} & 地 $\left(r_{1}\right)$ & 新鮮な岩石の露出地 \\
\hline & 深 層 風 化 地 $\left(r_{2}\right)$ & $\begin{array}{l}\text { マサ状風化または風化層の厚さが } 1 \mathrm{~m} \text { 以上の } \\
\text { ところ }\end{array}$ \\
\hline & 風 化 岩 石 地 $\left(r_{3}\right)$ & $\begin{array}{l}\text { 風化岩石地, 風化土混り風化岩石地, 亀裂が } \\
\text { 多〈䏛な石地 }\end{array}$ \\
\hline \multirow{4}{*}{$\begin{array}{l}\text { 地 } \\
\text { 質 } \\
\text { 区 }\end{array}$} & 古 生 層 $\left\{\begin{array}{l}\text { ホルンフエルス } \\
\text { チャート }\end{array}\right.$ & $\begin{array}{l}\text { 砂岩も含める } \\
\text { 砂岩または粘板岩が熱変成を受けたもの }\end{array}$ \\
\hline & 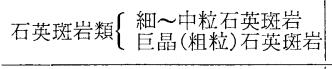 & 現地で確認した地域のみ図示 \\
\hline & 石 英 閃 緑 岩 & \\
\hline & 安 山 岩（皇海山 安山岩） & $\begin{array}{l}\text { 皇海山を中心として分布するもので, 数枚の } \\
\text { 愹岩流, 火山砕層岩よりなる。皇海山北腹の } \\
\text { 変質带も図示 }\end{array}$ \\
\hline \multirow{4}{*}{ そ } & 崩 填 地 & $\begin{array}{l}\text { 特に崩塤の進行顕著な箈所を，崩壤地としし } \\
\text { て図示した }\end{array}$ \\
\hline & 侵 食 路 & 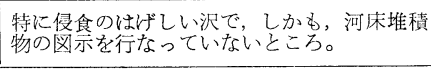 \\
\hline & 断層 & $\begin{array}{l}\text { 現地調査または空中军真判読により確認され } \\
\text { るもの }\end{array}$ \\
\hline & 台風26号時の侵食河岸 & とくに侵蝕のはげしい部分のみを図示 \\
\hline
\end{tabular}

3）クリーピングが現に起っているか または起り易い古生層地域 (C)。

4）凍結融解により地表面がゆるんだ 南向斜面地域 $(S)$ 。

5）風化（礫化・マサ化）により滑落 のある地域 $(W)$ 。

6）断層・破挽带等の影響で土砂生産 が行なわれる地域 $(\mathrm{F})$ 。

7）節理面からの崩壊により土砂生産 が行なわれる地域( J )。

8）鉱化帯から土砂生産が行なわれる 地域 $(M)$ 。

9）火山変質帯から土砂生産が行なわ れる地域 (A)。

区分はあくまで定性的で，従って作業 の指標となるのは，現地で観察した土砂 生産のタイプ地が，写真上でどう見壳る かといら対応性の判断と記憶にほかなら ない。このため,一人で行なわない限り 判読者の経験 ・能力等により, 区分に多 少主観的差異が生ずるのは否めない。

また，土砂生産の機構や崩填原因は， われわれが頭の中で考えるよりも実際に ははるか複雑で，これを単一要素にし ぼること自体相当の無理があるが，便宜 上対象小区域ごとに最も卓越する要素を もって代表させ，さらに将来の土砂生産 の危険度あるいは量的影響度を判断して 階級区分を行なった(図一 3 次貢)。

\section{4. モデル区域の選定}

いて，適当な小区域ごとにタイプ分けし，さらにそれ らを土砂生産の程度によって 5 階級に区分した。最終 的には小区分された各タイプ・階級の中から適当数の モデル地を選び，ある期間を和いて撮影した空中写真 の比較計測から, 変動深を求め, 生産土砂量を算出 し，これを全域に普遍化して全生産量を算出するのが ねらいである。

区分基準は，当地域で過去に蓄積された経験や調査 結果に基づき，あらかじめ土砂生産機構あるいは崩壊 原因と目される要素を選定して扣き，新たな現地踏査 により実情に合うよう適宜修正を加え，下記のごとく 定めた。

1）火山灭地（ローム）で，主に谷頭侵食により土 砂生産が行なわれる地域 (L)。

2）崖錐・段丘堆積物等の未固結堆積物の侵食, 移 動により土砂生産が行なわれる地域 ( T)。
全域について作成した土砂生産機構区分図の中か ら，階級 3 以上のものについて実際に航測を行なう， 2 時期間の侵食量の算出基準となるモデル区域を選定 した。ここでは主として，(1)土砂生産の大勢を支配す る機構・原因は何か，(2)他の方法（たとえば河床横断 測量など）で測定した方が都合がよいものはどれか， (3)地形的制約 (対空標識設置と基準点測量の可能 個 所)，(4)経済的制約(測定できるモデル区域の数に限度 がある）などの要素を考虑して，足尾えん堤上流付近 を中心に20個所を選定した(図一 4 次项)。1 個所の大き さは $100 \times 100 \mathrm{~m}$ 原則としたが，地形的条件で多少変 えたところがある。

\section{5. 方眼間隔の検討}

モデル区域の平均侵食深算出のため，ある一定間隔 をもった方眼点の標高の経年変化を，航測により読不 


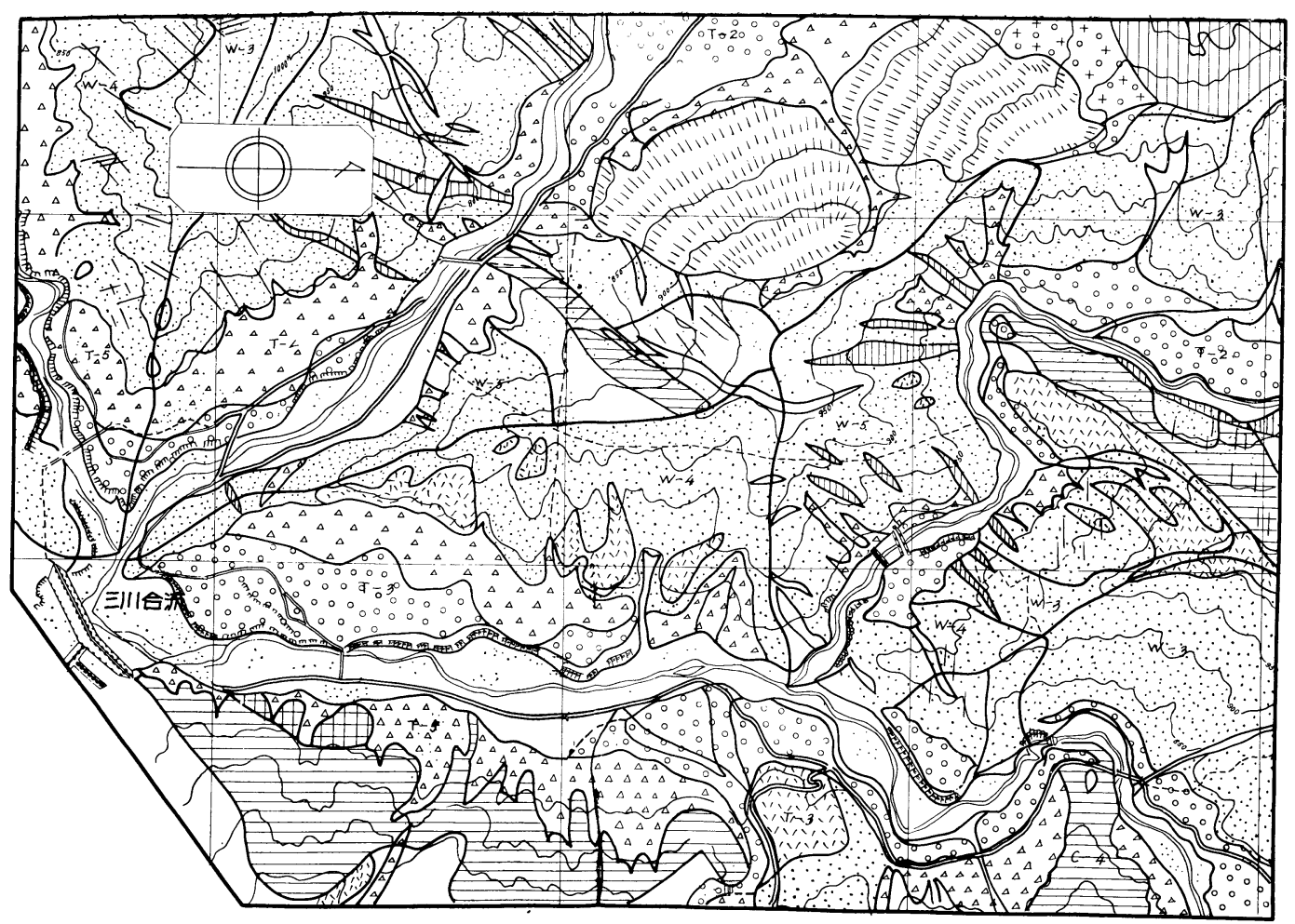

図一3 土砂生産機構区分図の一部

凡 例

地筫区介

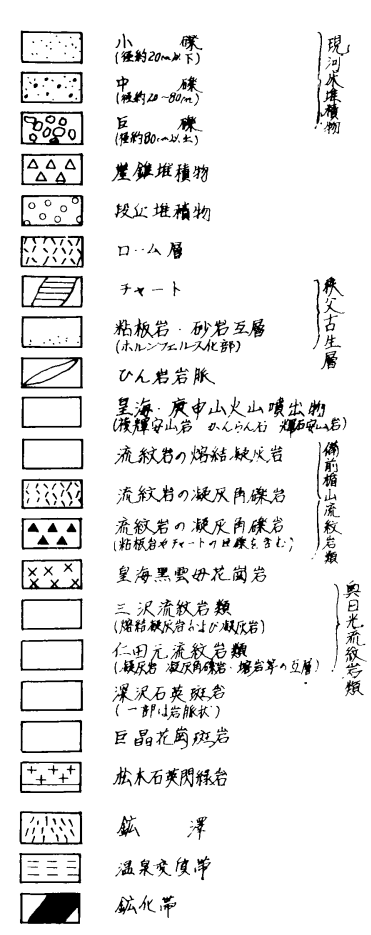

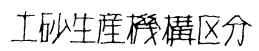

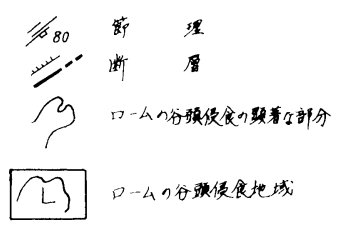

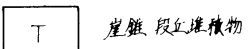

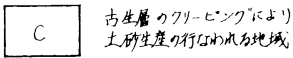

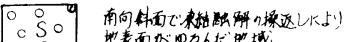

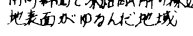

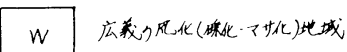

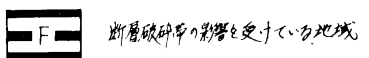

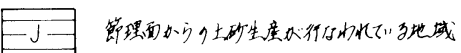

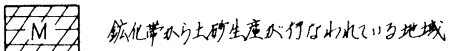

火山变傎带秥大化都方方

土砥生度が行的风ている地域
工砂生産階級区分

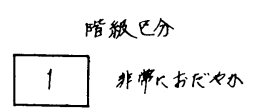

2 おドかか

3 中程度

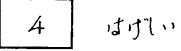

5 非常火小げしい 


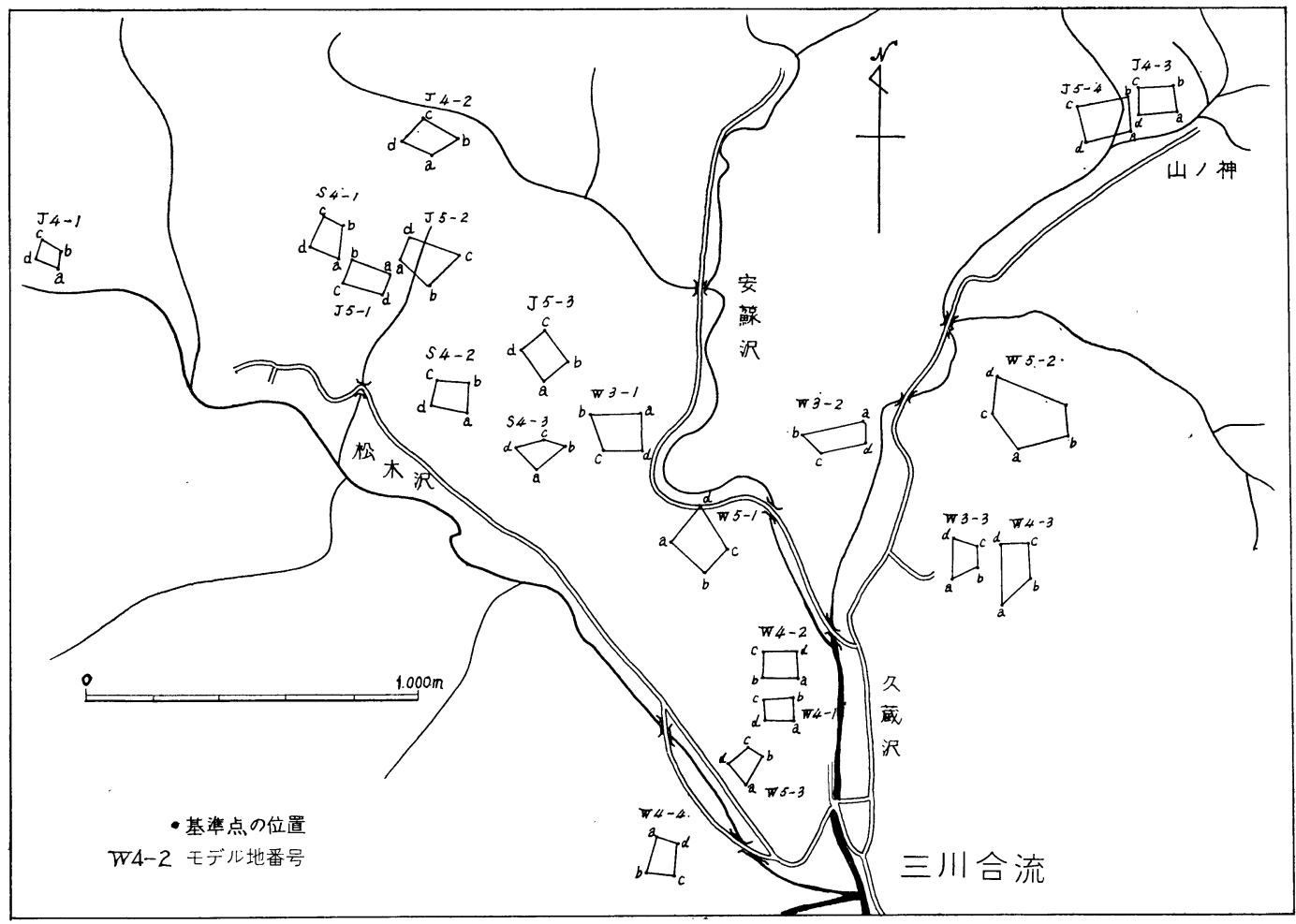

図一4 モデル地位置図

とった。それに先だち, 労力的・経済的かつ精度上, 最も適切な方眼間隔を知るために，20個所のモデル区 域以外に, $26 \mathrm{~m} \times 26 \mathrm{~m}$ の方眼間隔検討専用のモデル地 （測定モデル区域W4-1，W4-2の地区に含まれる区 域）を設定し，本作業と同一条件で検討した。方眼間 隔決定の際の条件は，下記のと特りである。

（1）空中写真の撮影縮尺は $1 / 1,000 〜 1 / 1,200$ とする

(2) 標高読定はステレオプラニグラフC 8 による。

(3) 方眼間隔は細かくとる汪ど望ましいが，一応 $0.5 \mathrm{~m} \times 0.5 \mathrm{~m}$ 方眼の值を真の值と仮定する。

(4) 測定誤差は正規分布するものとする。

$0.5 \mathrm{~m}$ 方眼で測定した場合の 2 時期間の平均侵食深 を，便宜上侵食深の真の值と仮定し，この值に対し $1.0 \mathrm{~m} \times 1.0 \mathrm{~m}, 1.5 \mathrm{~m} \times 1.5 \mathrm{~m} \cdots \cdots$ 等各種の方眼の 4 隅 で測定した平均侵食深が，方眼間隔の差異によりどう 変るかを検討した(表一 2 , 図一 5 次頁)。

その結果，方眼間隔により相当のバラッキがある が，概して間隔が小さくなるほどバラッキが少なく， 当然 $0.5 \mathrm{~m}$ 万眼の平均侵食深との差自体も小さくなる。 $2 \mathrm{~m} \times 4 \mathrm{~m}$ 以上ではバラッキが大きくて不明確だが， $0.5 \mathrm{~m}$ 方眼の場合の平均侵食深との差異は， $3 \mathrm{~m} \times 4 \mathrm{~m}$ 以上ではほぼ横ばい状態となるのに対し，これ以下で はほぼ方眼の面積に比例して増大している。
ステレオプラニグラフ C 8 の精度は，撮影縮 尺 $1 / 1,000 \sim 1 / 1,200$ の写真を使用した場合， $1.8 \mathrm{~cm} \pm$ と される。また，各方眼ごとの測定総点数が，作業量を 示すと考えてもよく（箃密には測定のみならず標定な

表-2 同一モデル地内における方眼間隔のちがい による平均侵食深のちがい

\begin{tabular}{|c|c|c|c|}
\hline \multicolumn{2}{|c|}{$\begin{array}{c}\text { 方 眼 間 隔 } \\
(\mathrm{m})\end{array}$} & $\begin{array}{c}\text { 平均侵食深 } \\
(\mathrm{cm})\end{array}$ & $\begin{array}{l}\text { 真の值 }(-27.5 \mathrm{~cm}) \\
\left.\text { との差 }{ }_{(\mathrm{cm})} \text { 註 } 1\right)\end{array}$ \\
\hline 1 & $1.0 \times 1.0$ & -27.5 & 0 \\
\hline 2 & $1.0 \times 1.5$ & -27.7 & +0.2 \\
\hline 3 & $1.5 \times 1.5$ & -27.5 & 0 \\
\hline 4 & $1.5 \times 2.0$ & -26.5 & +1.0 \\
\hline 5 & $2.0 \times 2.0$ & -29.4 & +1.9 \\
\hline 6 & $2.0 \times 3.0$ & -27.4 & -0.1 \\
\hline 7 & $2.5 \times 2.5$ & -26.7 & -0.8 \\
\hline 8 & $2.0 \times 4.0$ & -26.4 & -1.1 \\
\hline 9 & $3.0 \times 3.0$ & -25.0 & -2.5 \\
\hline 10 & $3.0 \times 4.0$ & -30.1 & +2.6 \\
\hline 11 & $3.5 \times 3.5$ & -28.2 & +0.7 \\
\hline 12 & $4.0 \times 4.0$ & -24.9 & -2.6 \\
\hline 13 & $4.0 \times 5.0$ & -23.3 & -4.2 \\
\hline 14 & $4.5 \times 4.5$ & -23.5 & -4.0 \\
\hline 15 & $4.0 \times 6.0$ & -25.8 & -1.7 \\
\hline 16 & $5.0 \times 5.0$ & -24.8 & -2.7 \\
\hline 17 & $5.5 \times 5.5$ & -24.4 & -3.1 \\
\hline 18 & $6.0 \times 6.0$ & -26.0 & -1.5 \\
\hline 19 & $5.0 \times 8.0$ & -29.6 & +2.1 \\
\hline 20 & $6.5 \times 6.5$ & -31.4 & +3.9 \\
\hline
\end{tabular}

註 1） $0.5 \mathrm{~m} \times 0.5 \mathrm{~m}$ 方眼での平均值を真の值と仮定した。 


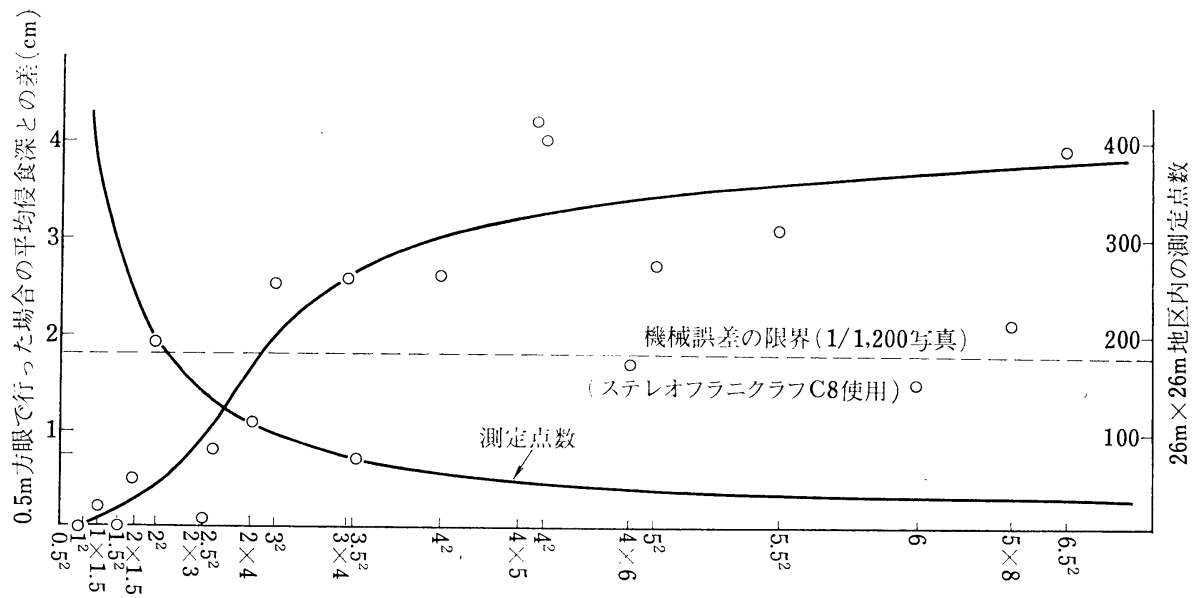

(广j腿間傒)

図一 $50.5 \mathrm{~m}$ 方眼で切った場合の 2 時期間の平均侵食深と各種方眼間隔で切った場合の平均侵食深の差

ど固定的な部分もかなりあるが)，これは方眼間隔の ほぼ 2 乗に逆比例する。

検討の方法にも問題があるが*，一応以上の要素を 考えると, $2 \mathrm{~m} \times 4 \mathrm{~m}$ 程度が妥当であろらという結諭を 得た。しかし，山腹傾斜の急な部分では，水平方向の 読定誤差が高さの䛊差に著しく影響するため，20個所 のらち 6 個所については，安全をみて $2 \mathrm{~m} \times 2 \mathrm{~m}$ の間隔 で測定した。

\section{6. 基準点設置と撮影}

モデル区域20個所について現地踏查の後，対空標識 アルミ板を鉄柱で固定）を設置し基準点とした。基準 点は，距離をジオジメーター，方向と各点間の比高を トランシット（20秒読み）により測定した。

基準点はモデル区域に 3 点でよいが，2 回目以降の 標定はこれら基準点をもとに行ならから，一点でも変 位すると正確な標定ができない。このうちの一点が変 位しても標定が可能で, さらに正しい 3 点により変位 した1点を測定しな执せるようにした。2 年目には再 踏查を行ない，対空標識の点検とペンキの塗りかえを 行なったが，実測による標高のチェックはしていな い。

基準点は，ほとんどモデル区域の内側に設置した が，2回目测定時の標定結果からすると，モデル区域 から一定距離沶いた外侧に配する方が標定しやすく, 精度もよいことがわかった。

* $0.5 \mathrm{~m}$ 方眼の平均標高差を真の値と仮定したこと。また， 厳密な意味ではこのモデル地でのみこのような結諭が得 られるのであって, 従ってモデル地が足尾地区の全裸地 地城を代表しているとい5大前提がなければ，これをと のまま全城にあてはめることはできない。
モデル区域の撮影には，防震装置を有するべル式 $\mathrm{KH}-4$ 改 I 型ヘリコプターを使い，初回を1969年11月 に，2回目を1971年1月に行なった。80\%のオーバラ ップで撮ったため，一モデル区域あたり 1 一 2 モデル の写真枚数となった。

\section{7. 測 定}

モデル区域での方眼点の標高測定には高精度が要求 されまたモデル区域内での高度差も大さいため，ス テレオプラニグラフC 8 を使った。読定は $\mathrm{cm}$ の単位 まで読及とり，後の計算に電算機を使う関係上，測定 倠はさえ孔テープにとった。测定に先だち各モデル区 域内の基準点の標定を行なったが，2 時期の基準点の 標高は，必ずしも一致しなかった(表一 3 )。

標高読定に際し，测定点が樹木と一致する部分，残 雪のある部分，オーバーハングした部分などの測定は 不可能恋ため，計算から除外した。

\section{8. 測定結果}

各モデル区域ごとに測定した結果は，(表一4次頁)に 示した。このうち，W3-1，W3-2，W5-1は，2回目 の写真撮影時に多少残雪があり，測定点総数が少ない ので平均值の算出の際には除いた。

測定結果をみると，当初の予想に反してW 5 とW 4 の值が逆転した。W 3 は，多少植生被覆があって侵食 もごく少なく，当初から平均侵食深は０に近いと考觉 て和り，結果も予想ど括りであった。ところが，雪の あったW5-1 を除外しても全体とするとW 4 とW 5 と では, 予想 (土砂生産機構区分図) と逆に出ている。 このことは，同図上でW（砂化・マサ化を主機構とす 
表-3＼cjkstart基準点の標定誤差

\begin{tabular}{|c|c|c|c|}
\hline 基準点No. & $\begin{array}{l}\text { 図化機に㨞基準 } \\
\text { 美差 }\end{array}$ & 基準点No. & $\begin{array}{l}\text { 図化機に比ける基準 } \\
\text { 点の標定差 }\end{array}$ \\
\hline \multirow{4}{*}{ W $5-1$} & $1^{(\mathrm{cm})}$ & \multirow{4}{*}{ J $5-1$} & $0^{(\mathrm{cm})}$ \\
\hline & -3 & & 0 \\
\hline & 2 & & 1 \\
\hline & 0 & & -1 \\
\hline \multirow{5}{*}{ W $5-2$} & 0 & \multirow{4}{*}{ J $5-2$} & 2 \\
\hline & 0 & & -1 \\
\hline & 0 & & 1 \\
\hline & - & & -1 \\
\hline & - & \multirow{4}{*}{ J $5-3$} & 0 \\
\hline \multirow{4}{*}{ W $5-3$} & 0 & & 0 \\
\hline & 0 & & 0 \\
\hline & 0 & & - \\
\hline & 0 & \multirow{4}{*}{ J $5-4$} & 2 \\
\hline \multirow{4}{*}{ W $4-1$} & 0 & & -2 \\
\hline & 0 & & 2 \\
\hline & 0 & & -2 \\
\hline & 0 & \multirow{4}{*}{ J $4-1$} & 0 \\
\hline \multirow{4}{*}{$\mathrm{W} 4-2$} & 0 & & 0 \\
\hline & 0 & & 0 \\
\hline & -1 & & 0 \\
\hline & 2 & \multirow{4}{*}{$\mathrm{J} 4-2$} & $25^{*}$ \\
\hline \multirow{4}{*}{$\mathrm{W} 4-3$} & 0 & & -14 \\
\hline & 0 & & 10 \\
\hline & 0 & & -21 \\
\hline & - & \multirow{4}{*}{ J $4-3$} & 3 \\
\hline \multirow{4}{*}{$\mathrm{W} 4-4$} & 0 & & -3 \\
\hline & 0 & & 2 \\
\hline & 0 & & -2 \\
\hline & - & \multirow{4}{*}{ S $4-1$} & 3 \\
\hline \multirow{4}{*}{ W $3-1$} & 3 & & 0 \\
\hline & -2 & & 0 \\
\hline & 2 & & -3 \\
\hline & -2 & \multirow{4}{*}{$S 4-2$} & 0 \\
\hline \multirow{4}{*}{ W $3-2$} & 0 & & 0 \\
\hline & 0 & & 0 \\
\hline & 0 & & 0 \\
\hline & - & \multirow{4}{*}{$\mathrm{S} 4-3$} & 0 \\
\hline \multirow{3}{*}{ W $3-3$} & 0 & & 0 \\
\hline & -2 & & 0 \\
\hline & 2 & & 0 \\
\hline
\end{tabular}

* 他のものより注ぼ 1 ケ大きい数值となっているが, 何に原因する のか不明である。

る生産地域）での階級区分が不適当であったことにな る。

そのほか，J 5-3がー $26 \mathrm{~cm}$ と当初の予測よりも少し 大きめ出ているようであるが，その值の妥当性につ いては何ともいえない。また，J 5-2，J 4-3などで侵 食深が 0 となっているが，後述のごとく崩壊物のカサ 増しによる堆積量の增加で, 侵食深が打消された可能 性があり，本当に0亿近いのかどらか問題がある。

測定した侵食深を土砂生産機構と階級別汇機戌的江 平均すると，(図一6次頁)のごとくなる。また（図一7 次面）は，モデル区域W4-1 亿抹恬る平均的侵食深を図
示したものだが，当地域のごとく全面的裸地域 域での侵食も,厳密沈は決して面状侵食 (Sheet Erosion）に上るものではないことがわかる。 このことは，判読結果（ガリ一部分以外での侵 食や堆積は，判読では注とんど変化がわからな いが）ともよく一致する。

\section{9. 総生産土砂量算出結果}

表一 4 亿示した各タイプごとの侵食深の階級 別平均值に，各分布面積を乗じて，足尾三川地 区の1969年11月～1971年 1 月間の生産土砂量を 求めた(表一5 次頁)。その結果，当地区で約 65 万 $\mathrm{m}^{3}$ の土砂が生産されたことになる。この值は， 測定誤差の問題を別比し考兵ると，全くの侵 食量といらことになる。ただ，崩壊物のカサ増 しについての考慮はしていないから，土砂にほ ぐれた場合の実際の侵食量は，この值より大き くなる可能性がある。

得られた值が妥当なものかどらかが問題であ るが，今後つぎのような方面から検証する必要 があるう。

1) 溪床堆積物の調查（河床変動量調査にも 山腹侵食量調查にもかからない部分）

2）河床変動量調查

3）流砂量調查（足尾光几堤より下流へ流出 した土砂量の調查）

\section{0. 測定精度の検討}

ここに示した方法に扔ける測定精度は，(1)基 準点の誤差，(2)撮影時の誤差，(3)標定誤差，(4) 標高測定時の誤差，(5)方眼間隔による誤差，な どにより規制される。

基準点測量は，距離をジオジメーター，標高 差をトランシット（20秒読み）により測定し た。従って, 基準点の距離の誤差は $5 \mathrm{~mm}$ 程度 $( \pm 5 \mathrm{~mm} \mathrm{~S} / 1,000,000 \mathrm{~cm})$ と考えてよい。一 方高さの誤差は，基準点間の仰角は最大 $30^{\circ}$ 程度であ るから，トランシットの測角誤差を $20 "$ としても，最 大 $1 \mathrm{~cm}(d h=d s \sin \theta+d \theta \cdot s \cos \theta)$ となる。

撮影時の誤差の中には，カメラのもつ誤差と撮影条 件による誤差が含まれ，前者には，レンズの収差（半 径方向, 切線方向拉よび非対称性によるわい曲收差と 色收差), カメラ誤差 (光軸, 主点位置, 画面距離な どの誤差)，フィルムムの誤差(感光剤の粒状性, 局部伸 縮，温度抢よび温度，平行性などの誤差）があり，後 者には大気の屈折, 飛行機の移動, カメラの振動なぞ の誤差が含まれる。それらを写真上の誤差として表現 


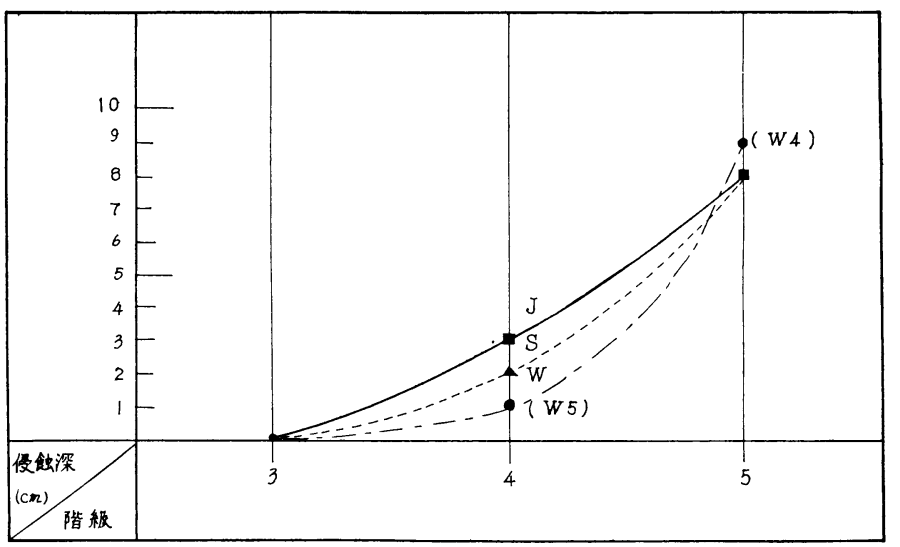

図一6 土砂生産機構別階級別の平均侵食深

表一 3 程度の標定誤差を生じ，その 平均値は土1. $8 \mathrm{~cm}$ 程度となる。

標高測定は（a)測定そのものの誤 差と(b)水平位置のズレからくる高さ の誤差，の 2 つを有する。一級図化 機を使い任意の点の標高を測定した 場合の測定誤差は，一般偮影高度 の $1 / 7,000 \sim 1 / 10,000$ と考光られて いる。本作業で使用した写真縮尺は

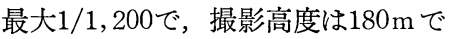
あるから，観測誤差は $1.8 \mathrm{~cm}$ 程度 となる。一方，(b)の方は水平面上で

すると，レンズの収差は $6 \sim 11 \mu$ ，カメラ誤差が 2.5 $\sim 5.5 \mu$ ，フィルム誤差が $5 \sim 11 \mu$ 程度である(尾崎 : 1968）。ふつら飛行機の移動誤差が最も大きく，その 他はほとんど無視できる程度である。しかるに，撮影 は防震装置つきのへリコプターで行なったため，その 移動誤差は写真上で $10 \mu$ 以下と推測される。

本来，2 時期間に打敉基準点の標高読定值の差は 0 となるはずであるが，標定に際しては主として図化 機の機械誤差または標識認定の個人差, 撮影条件の差 などからくる誤差をともない，最大限の努力をしても
は 0 であるが，傾斜地では傾斜角の大きさにより変化 する。測定すべき点の 2 時期間の水平方向のズレは, 測定時に使ら方眼図上で約 $0.1 \mathrm{~mm}$ 程度で, これは展 開図面の縮尺(1/400)を考慮すると, 実長で平均 $4 \mathrm{~cm}$ となる。モデル地内の傾斜を少し大き目にみて仮に $30^{\circ}$ とすると, これにより平均 $2.4 \mathrm{~cm}$ の䛊差を生じる ことになる。さらに，方眼間隔による誤差は， $2 \mathrm{~m} \times$ $4 \mathrm{~m}$ 方眼の場合で $1 \mathrm{~cm}$ 程度であるから(図一 5 ), 以 上の誤差を誤差伝播法則により合計すると, 平均士 $3.6 \mathrm{~cm}$ となる。

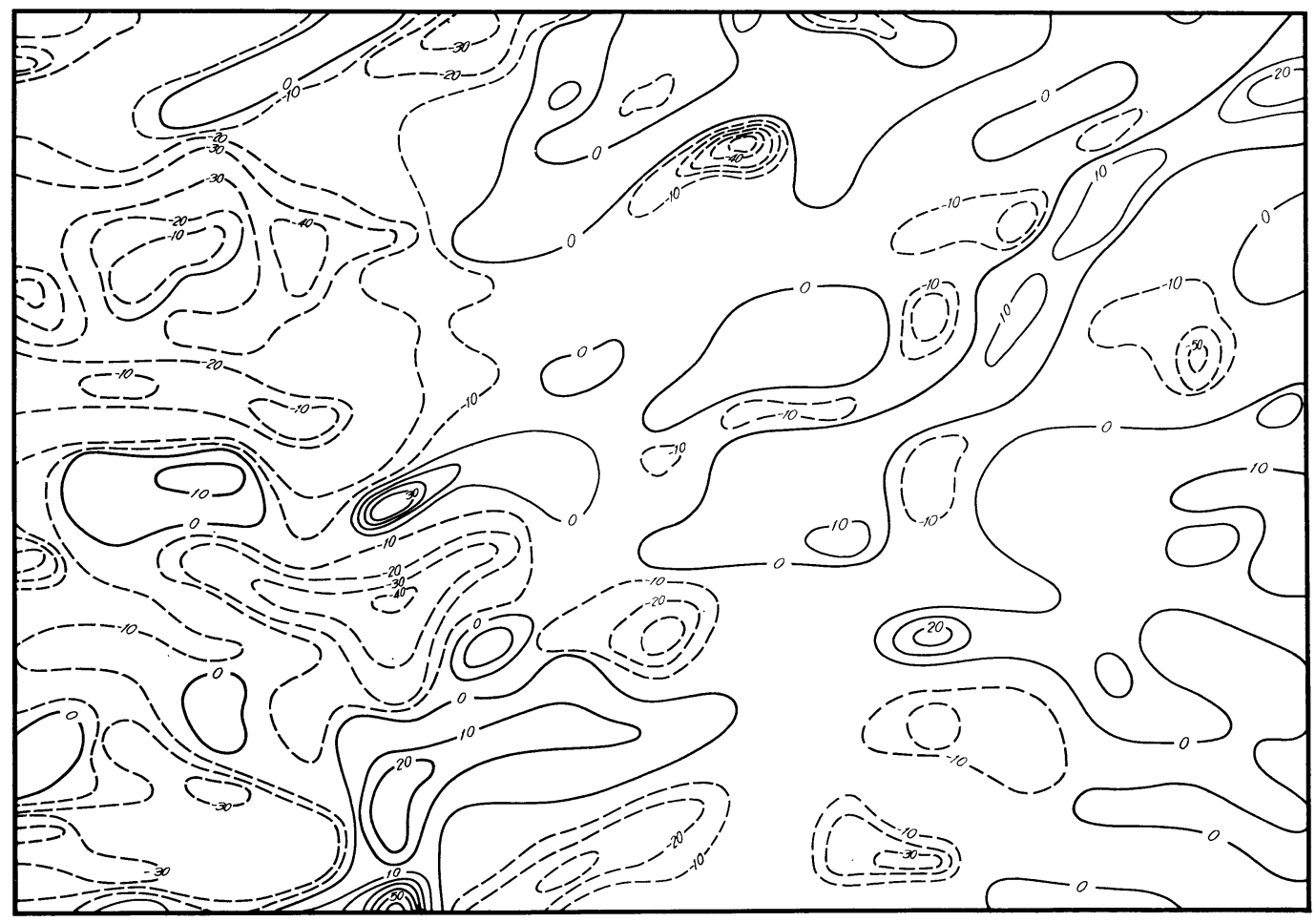

図一 7 侵食と堆積の変化(W 4-1 の一部)

（実線は堆積，破線は侵食を示す。単位 $\mathrm{cm}$ ) 
表-4 モ デ ル 地 一 覧 表

（1969年11月～1971年 1 月間の変化）

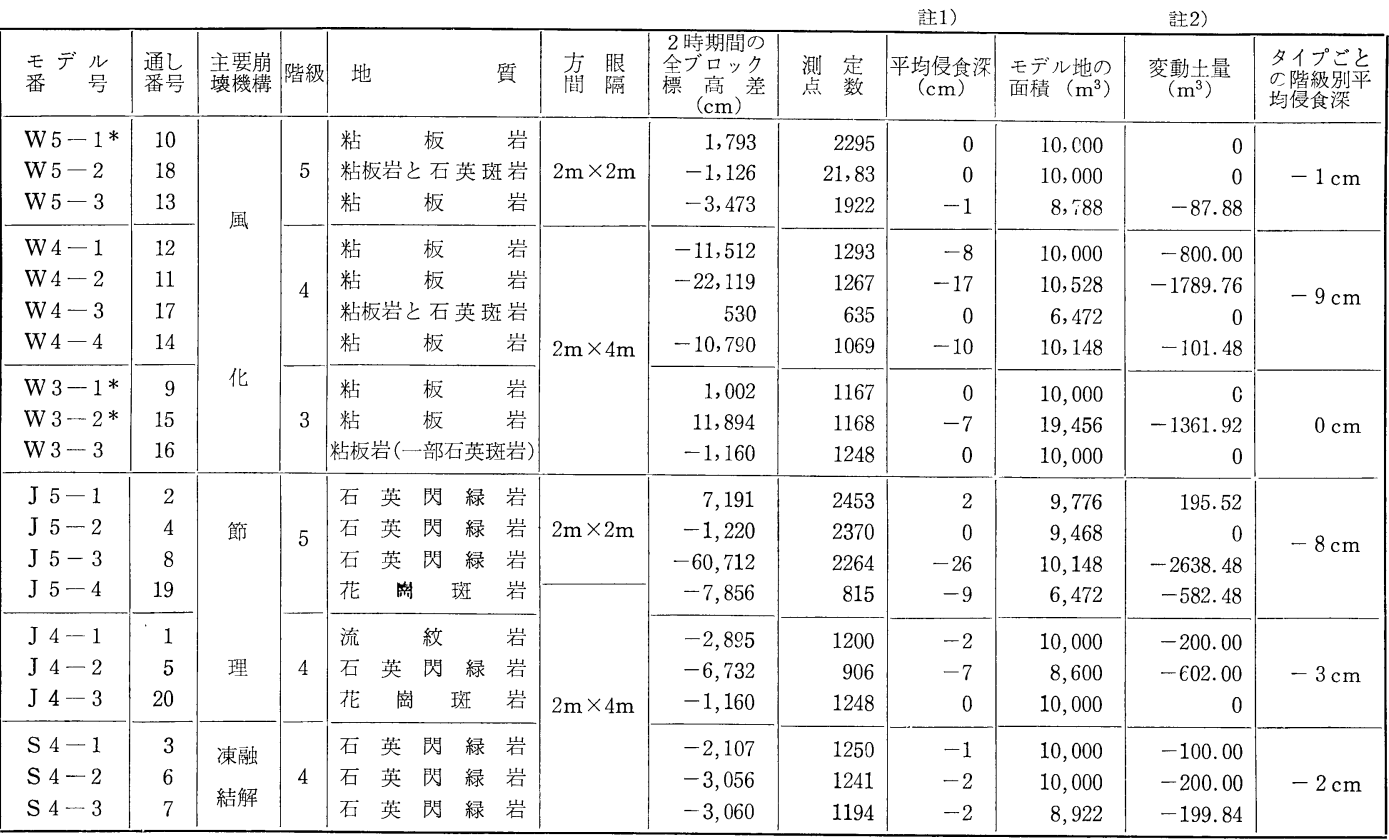

註 1 ) 小数点以下切捨

註 2 ）平均侵食深×モデル地面積

* 雪の部分の多かったサンプル・モデル地については, 平均值算出の際には除いた。

\section{1. 問 題 点}

本方法により斜面の表面侵食量を測定する場合，次 のような点で多少問題がある。

\section{1）土砂生産機構区分図の妥当性}

同図は主として，1966年撮影のカラー写真を用いて 判読・作成したもので，この時点での荒廃状況を定性 的に表現区分したものであり，定量的裏つけのもとに 区分されたものではない。従って，同図を使用するに 際し，崩壊現象を固定的なものとして扱ってよいもの かどうか疑問が残る。例㝑ば，同図で土砂生産階級が 5 にランクされた個所を，果していつも5であると考 えてよいものかどらかといらことである。

今回の測定結果からみると，大まかにみてある線ま では固定的に考劣てさしつかえなく，それを越えると 非常に流動的になると考える必要があるように思われ る。例えば， 2 や 3 の階級のものが $2 \sim 3$ 年の短期間 で，4や 5 の階級に変るとは考えられないが，4また は 5 のものが，5や4へ変るといらことは充分に考光 られる。

\section{2）新規崩壊のとり扱い}

根本的には前項と同じ問題で, 土砂生産機構図を固 定的なものとしているため, 新規崩壊（植生被覆地域 に生じた新たな崩壞）からの生産土砂は, 本方法では 考慮されていない。植生地区では，特に顕著な気象異
常がない限り，新規の崩壊が起こることは少ないが， 当地区は経験的に 4,5 年に一度ほどの確率で起るよ らであるから，新規崩壊からの生産土砂を無視するこ とはできない。

ただ，新規崩壊地からの土砂生産量の把握は，豪雨 型崩壊における調査方法がそのまま適用可能である。

\section{3) Sheet Erosion の仮定}

一度形成された崩壊地（裸地）での土砂生産は，面 状侵食 (Sheet Erosion) の形で行なわれるといら仮 定でこの調査をすすめてきた。しかしながら，今回の 測定結果からみると，同一モデル区域内でも侵食に著 しい差異があるだけでなく，侵食部分と堆積部分とが 共存して打り(図一7), 厳密な意味での Sheet Erosion ではない。ただ，侵食深の平均值を得るための一 手段として, 便宜上モデル区域内では Sheet Erosion が行なわれると仮定するのは構わないであろう。

\section{4）斜面中腹の崖錐と崩壊物のカサ増し}

生産土砂が崖錐として麓部に堆積した場合には，ふ つら分布状況も明瞭で実作業上は河床横断測量の測線 を，崖錐部分まで延すことにより，量的変化を把握で きる。また，崖錐下の地山の侵食は行なわれないと考 えてよい。ところが，山麓まで達せず中腹に滞留して いる場合には, 測定された侵食深は次のような理由か ら信頼性がおちる。

（1）中腹の崖錐は, 上から流入した土砂量と, その部 
表-5 足尾地区土砂生産量

\begin{tabular}{|c|c|c|c|c|c|c|}
\hline $\begin{array}{l}\text { 階 } \\
\text { 区 }\end{array}$ & 級 & 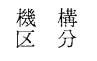 & 面 積 (a) & 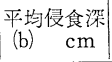 & $\begin{array}{l}\text { 生産土砂量 } \\
\mathrm{a} \times \mathrm{b} \mathrm{m}^{3}\end{array}$ & 考 \\
\hline 1 & 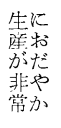 & $\begin{array}{l}\text { 柀生被覆 } \\
\text { 地域 }\end{array}$ & $31,806,480.25$ & 0 & 0 & $\begin{array}{l}\text { 侵食深(b)を } 0 \text { と仮定。 } \\
\text { すなわっ, 新規崩壊む } \\
\text { ないものと仮定しての } \\
\text { 計算。 }\end{array}$ \\
\hline
\end{tabular}

\begin{tabular}{|c|c|c|c|c|c|c|}
\hline \multirow[t]{2}{*}{2} & \multirow[t]{2}{*}{ 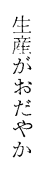 } & $\begin{array}{l}S \\
J \\
W \\
T\end{array}$ & $\begin{array}{r}26,307.25 \\
2,068,265.75 \\
754,393,25 \\
287,896,00\end{array}$ & $\doteqdot 0$ & $\doteqdot 0$ & \multirow[t]{2}{*}{ 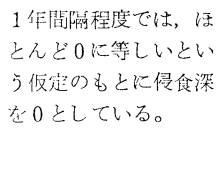 } \\
\hline & & 小 計 & $3,136,862.50$ & & & \\
\hline
\end{tabular}

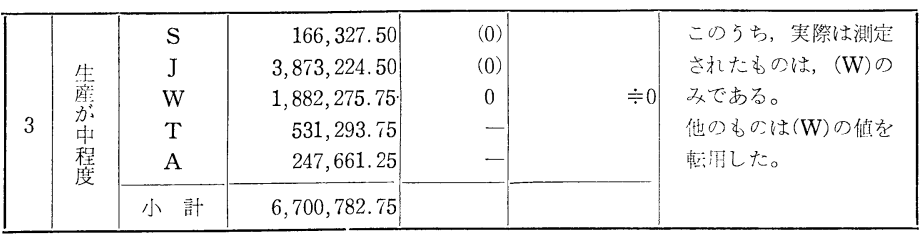

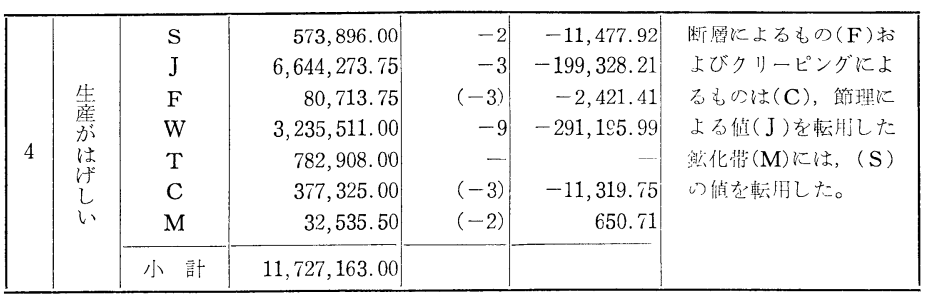

\begin{tabular}{|c|c|c|c|c|c|c|c|}
\hline \multirow{8}{*}{5} & & $\mathrm{~s}$ & $67,047.75$ & $(-8)$ & $-5,363.82$ & \multirow{8}{*}{ 同 } & \multirow{8}{*}{ 上 } \\
\hline & 告 & $\mathrm{J}$ & $1,342,317.75$ & -8 & $-107,385.42$ & & \\
\hline & s & $\mathrm{F}$ & $8,499.75$ & $(-8)$ & -679.98 & & \\
\hline & 韭 & W & $786,078.00$ & -1 & $-7,860.78$ & & \\
\hline & v & $\mathrm{T}$ & $458,885.25$ & - & - & & \\
\hline & は & C & $129,128.50$ & $(-8)$ & $-10,330.28$ & & \\
\hline & L & M & $16,754.50$ & $(-8)$ & $-1,340.36$ & & \\
\hline & & 小 計 & $2,808,711.50$ & & & & \\
\hline
\end{tabular}

\begin{tabular}{|l|l|l|l|l|}
\hline 合 計 & & $56,180,000.00$ & 約1.2cm & $-€ 49,354 . € 3$ \\
\hline
\end{tabular}

註 1）平均侵食深の5ち（）を付したものは，他の值を転用したすの。

分からさらに下へと流出した量との差引量があらわ れているにすぎない。すなわち，崖錐下の地山の侵 食を反映しないだけでなく，実際には地山の侵食が あっても，その後上から新たな土砂供給があって， 逆の現象（標高の增加）として表現されることもあ り，モデル区域全体として，このような原因による 標高の増加部分と侵食による減少部分とが，打消し 合うことがある。

（2）その上，崩壊物のカサ増量（硬岩の場合約1.7倍） が加わるのも見逃せず，中腹の崖錐の体積が大きく なり，地山の侵食による減少とが打消し合う現象が 起りえる。

従って，この種の崖錐部分は，錐雪や木などと同様測 定の際涂外するのが望ましいが，実際汇は分布が狄 かったり堆積が薄かったりすると，判別が難かしい。

\section{まとめ}

1）小論は，写真判読と大縮尺写真 を使った写真測量とを応用して， 足尾三川地区の裸地地域からの生 産土砂量を算出した結果について 述べたものである。

2）測定に先だち，写真判読と踏査 により山腹の性状を定性的に示し た「砂防・治山立地区分図」と 「土砂生産機構区分図」を作成し た。前者は, 自然の山腹形態を上 位より優先させて表現したもので 山腹基礎工や植生工の基礎資料と なる。後者は，土砂生産量算出の ための基礎的図面で，全域を土砂 生産機構とその程度によって区分 した。

3）土砂生産機構困をもとに，機構 之程度別に 20 個所のサンプルモデ ル区域 $(100 \mathrm{~m} \times 100 \mathrm{~m}$ 基準と乙 た）を選定し，各モデル地内での 2 時期(1969年11月と1971年 1 月) の写真の比較計測により侵食深を 求め, 各モデル地の面積を乗じて 生産土砂量を算出し，これを全域 に普遍化した。

4）各モデル地についての工程は,

(1) 4 点ずつの対空標識の設置とそ の基準点測量，(2)一級図化機によ る方眼上の標高測定，(3)モデル地 ごとの平均侵食深の算出，(4)対象 地域全域に打忛る生産土砂量の算 出などにわかれる。

5）機械計測に先だち，標高を測定する方眼間隔の検 討を行なった結果，当地区ては $2 \mathrm{~m} \times 4 \mathrm{~m}$ 方眼て行 なうのが，精度的・経済的に適当であることがわか

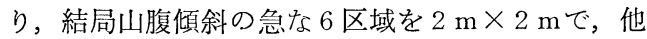
の14区域を $2 \mathrm{~m} \times 4 \mathrm{~m}$ て測定した。

6) その結果，この 2 時期間に対象とした足尾三川地 区 $56 \mathrm{~km}^{2}$ 全域から，約 65 万 $\mathrm{m}^{2}$ の砂が生産されたこ とがわかった。

7）本方法による標高の測定精度を検討してみると， $\pm 3.6 \mathrm{~cm}$ となる。

8）本方法で生産土砂量を算出する場合，(1)土砂生産 機構区分図の妥当性の問題（主として土砂生産を固 定的なものとして扱らことへの疑問)，(2)新規崩壊 の取扱い，(3)斜面中腹に分布する崖錐の取扱いと。 
岩盤が侵食されて土砂となった場合の岩石のカサ増 しの問題など，まだ解決さるべき問題も多い。

9）山腹の侵食量と測定精度とを考劣ると，災害前後 で行なら以外すなわち平常時では， $3 \sim 5$ 年間隔で 行ならのが妥当であるらと思われる。

10）本方法により算出される生産土砂量を，今後別の 方法によりチェックして，算出值全体についての精 度を検討してみる必要があるが，現在いかなる方法 でチェックするのが最も妥当か検討中である。

\section{参 考 文 献}

1）中山政一・今村遼平・川合恒孝・吉岡良朗(1967)，河
床変動調査に括ける航空写真の利用, 写真測量, Vol 6, No. 4

2）前橋営林局 (1967)，足尾三川地区治山立地調查報告書 国際航業(㑣調査

3）尾崎幸男 (1968), 写真測量の物理的限界, 写真測量, Vol. 7 , No. 3

4）関東地方建設局渡良瀬川工事事務所 (1969)，足尾地区 土砂生産調查報告書, 国際航業(㑣調查

5）関東地方建設局渡良瀬川工事事務所 (1968)，足尾地区 土砂生産調查報告書, 国際航業(森調查

6）東京電力㑣 (1969), 高瀨川地点・航空写真測定資料に よる，不動沢・濁沢両流城の崩壊・侵食・眝留ならび に流出土砂量の計算報告書, 国際航業(侏調查

7）関東地方建設局渡良瀬川工事事務所 (1971)，足尾地区 土砂生産調查報告書, 国際航業森調査 